\title{
Agreement Test of Histopathology in the Diagnosis of Extrapulmonary Tuberculosis with Gold Standard Polymerase Chain Reaction Technique: A Step to Overcome False Diagnosis
}

\author{
Ali Essa Shaker ${ }^{1}$, Mohammed Abdulmahdi Al Kurtas ${ }^{2}$, Haider Zalzala ${ }^{3 *}$ (D) \\ ${ }^{1}$ Department of Family Medicine, Ministry of Health, Baghdad, Iraq; ${ }^{2}$ Department of Pathology, University of Baghdad, Al-kindy \\ College of Medicine, Baghdad, Iraq; ${ }^{3}$ HLA Typing Research Unit, University of Baghdad, Al-kindy College of Medicine, Baghdad, Iraq
}

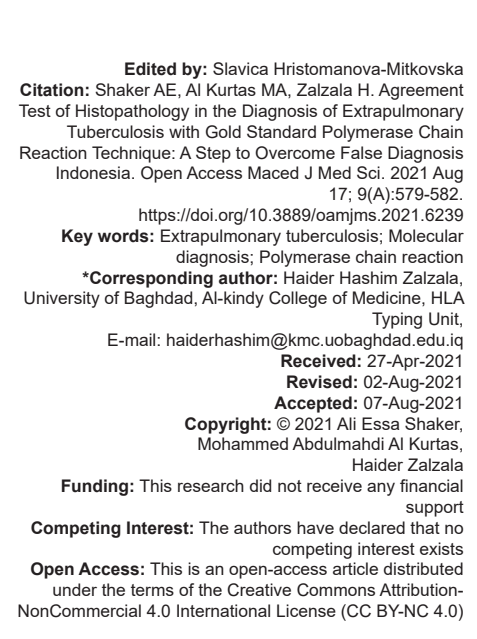

\section{Introduction}

Tuberculosis (TB) is a global health problem which is caused by Mycobacterium tuberculosis bacteria. It has been stated that one-quarter of the world's populations is infected by TB and only $10-15 \%$ of those develop the disease, while the remaining $85-95 \%$ of the population are carrying the bacteria and can't transmit the disease to the others. Ten millions will be ill every year most of them from low and middle-income countries and 1.5 millions die every year according to the WHO report [1]. $M$. tuberculosis bacteria affects the lungs, but any organ in the body can be affected by the bacteria. About $15 \%$ of TB infections are of in extrapulmonary type [1]. The most common sites for extrapulmonary tuberculosis (EBTB) are lymph nodes and pleura although other sites such as meninges, bones, intestines, and any other organs may be affected [2], [3]. The diagnosis of EPTB is very challenging because most sites are inaccessible and paucibacillary nature of the bacteria in these sites. Negative smear form acid-fast bacilli and absence of granuloma in histopathology and negative results from TB culture do not exclude the diagnosis [4]. The need for rapid and more sensitive and specific tests for the diagnosis of EPTB in comparison to culture and histopathology is increasing. Several attempts were tried such as the detection of adenosine deaminase detection in serum or effusion fluids but showed variable results [5], [6]. The molecular methods for the detection of TB gene(s) in the provided sample are now promising. In addition, many researches are published for this aspect with variable results [7], [8]. Some manufacturers tried to innovate a method for simultaneous detection of TB genes and the resistance 
gene, if present, in the same polymerase chain reaction (PCR) reaction, and some of manufactures success to get Food and Drug Administration approval for this innovation [9].

This study was designed to study the sensitivity of real-time PCR test in the diagnosis of EPTB in comparison to histopathology results.

\section{Patient and Methods}

This is a cross-sectional descriptive study carried out by collecting formalin-fixed paraffin-embedded (FFPE) blocks from laboratory for patients suspected to have EPTB from July, 01, 2015 to October 01, 2015.

Inclusion criteria necessitate that all patients should have suspected EPTB affecting any organ except the lung.

Exclusion criteria include any patient with EPTB affecting meningies, pleura, and any organ that necessities a body fluid sample for the diagnosis.

Sample size constituted from 74 patients both males and females are included in the study. Sample size was determined using Epi-Tools Epidemiological calculator with 0.95 confidence interval.

The study was done in accordance with Helsinki Declaration and it received a scientific and ethical approval.

\section{Histopathology examination}

Tissue samples were processed by standard wax techniques. The FFPE tissue blocks were cut in $4 \mu \mathrm{m}$ serial sections. The sections were stained with $\mathrm{H}$ and $\mathrm{E}$ method [10]. Then slides were evaluated microscopically at increasing magnifications $(\times 100$ $\times 400)$. Histopathologic Classifications as following:

- Caseating granulomas: TB granuloma displaying central necrosis with or without mineralization surrounded by macrophages, lymphocytes, plasma cell, neutrophils, epithelioid cells, and langhan's giant cells and enclosed partly or completely by a thin capsule. Were considered as strong evidence for TB [11]

- Non-caseating granulomas: Lesion characterized by irregular unencapsulated clusters of epithelioid macrophages but not langhan's type multinucleated giant cells and necrosis, were considered as weaker evidence for TB [11]

- Without granulomas: Features not consistent with TB granuloma, including significant eosinophilic infiltrates, lymphoid hyperplasia, and presence of bacterial colonies within necrotic area or tumors [11].

\section{DNA extraction from FFPE}

Five serial sections (5 $\mu \mathrm{m}$ thick) were cut from each paraffin-embedded tissue block by microtome blade and put in $1.5 \mathrm{~mL}$ eppendorf tube for DNA extraction (Leica 2135). For prevention of other contamination, the microtome blade was cleaned with xylene and absolute ethanol after each sample sectioning DNA was extracted from FFPE using promega extraction kit according to manufacturer instructions.

\section{MTB gene amplification}

DNA was amplified using exicycler 96 realtime PCR machine (Korea) and using Accupower MTB real-time PCR kit which amplifies the target MTB gene IS6110. The kit includes vacuum dried premix, positive control (PC), no template control,and internal PC in all wells to confirm correct PCR amplification. Final results were analyzed by Exidiagnosis software which automatically analyzes the test results based upon the threshold cycle $(\mathrm{Ct})$ value.

\section{Statistical analysis}

Analysis of data was carried out using the available statistical package of SPSS-20 (Statstical Packages for Social Sciences- version 20). Data were presented in simple measures of frequency, percentage, mean, standard deviation, and range (minimummaximum values). The significance of difference of different percentages (qualitative data) were tested using chi-square test (c2-test) with application of Yet's correction or Fisher Exact test whenever applicable. Statistical significance was considered whenever the $p<0.05$.

\section{Results}

A total of 74 different patients (18 males, 56 females) suspected to have extrapulmonary TB underwent biopsies from different tissue types with age between 2 and 58 years (mean age 29.72 years \pm 14.16 $\mathrm{SD})$. The biopsies were taken from different tissues according to the site of lesion as shown in Table 1.

For the 74 samples tested, 52 were positive by both PCR and histopathology (caseating and noncaseating granuloma favor TB) and five are positive for PCR with Negative histopathological result (Non specific granuloma not favoring TB) as shown in table 2. 
Table 1: Tissue type from whom tissue biopsy taken

\begin{tabular}{ll}
\hline Type of tissue & No. of biopsy (\%) \\
\hline Lymph node & $49(66.2)$ \\
Axillary mass & $12(16.2)$ \\
Abscess & $6(8.1)$ \\
Intestine & $4(5.4)$ \\
Fistula & $3(4.1)$ \\
Total & $74(100)$ \\
\hline
\end{tabular}

\section{Sensitivity, specificity, positive predictive} value, and agreement

In this study the sensitivity of histopathological examination of the biopsies was $91.02 \%$, the specificity $88.2 \%$, positive predictive value $96 \%$ and the kappa was $0.748(p=0.00)$ which is mean good agreement between histopathological examination of the biopsies and the polymerase chain reaction test.

Table 2: Relationship between histopathological result and polymerase chain reaction

\begin{tabular}{lllll}
\hline Histopathological & \multicolumn{2}{l}{ Polymerase chain reaction } & p-value & Total \\
\cline { 2 - 3 } examination & Positive & Negative & & \\
\hline Positive & $52(91.2)$ & $2(11.8)$ & $<0.000001$ & $54(100)$ \\
Negative & $5(8.8)$ & $15(88.2)$ & & $20(100)$ \\
Total & $57(73)$ & $17(27)$ & & $74(100)$ \\
\hline
\end{tabular}

From Tables 3 and 4 below, PCR gives high positive results in L.N biopsies as compared to other tissue biopsies and histopathology evidence (strong or weak evidence).

Table 3: Distribution of tissue biopsies with positive PCR test

\begin{tabular}{ll}
\hline Tissue type & Number of positive PCR (\%) \\
\hline L.N & $42(73.7)$ \\
Axillary mass & $8(14.1)$ \\
Abscess & $3(5.2)$ \\
Intestine & $2(3.5)$ \\
Fistula & $2(3.5)$ \\
Total & $57(100)$ \\
\hline PCR: Polymerase chain reaction &
\end{tabular}

\section{Discussion}

The diagnosis of EPTB is challenging issue with the need for rapid and highly sensitive and specific techniques. The diagnosis is mostly depending on histopathological examination of the sample. Although histopathology is considered a gold standard method for the diagnosis, this carries some limitations as the Table 4: Distribution of tissue biopsies with positive and negative PCR test in relation to histopathology evidence (strong or weak evidence)

\begin{tabular}{|c|c|c|c|c|c|}
\hline $\begin{array}{l}\text { Type of } \\
\text { biopsy }\end{array}$ & $\begin{array}{l}\text { Positive } \\
\text { PCR with } \\
\text { Histopathology } \\
\text { weak evidence } \\
\text { for TB }\end{array}$ & $\begin{array}{l}\text { Positive } \\
\text { PCR with } \\
\text { Histopathology } \\
\text { strong evidence } \\
\text { for TB }\end{array}$ & $\begin{array}{l}\text { Negative } \\
\text { PCR with } \\
\text { Histopathology } \\
\text { strong evidence } \\
\text { for TB }\end{array}$ & $\begin{array}{l}\text { Negative } \\
\text { PCR with } \\
\text { Histopathology } \\
\text { weak evidence } \\
\text { for TB }\end{array}$ & Total \\
\hline L.N & 0 & $42(85.7 \%)$ & 0 & $7(13.3)$ & 49 \\
\hline $\begin{array}{l}\text { Axillary } \\
\text { mass }\end{array}$ & 0 & $8(66.7)$ & 0 & $4(33.3)$ & 12 \\
\hline Abscess & $1(16.6)$ & $2(33.4)$ & $1(16.6)$ & $2(33.4)$ & 6 \\
\hline Intestine & $2(50)$ & 0 & $1(25)$ & 1 (25) & 4 \\
\hline Fistula & $2(75)$ & 0 & 0 & $1(25)$ & 3 \\
\hline Total & 5 & 52 & 2 & 15 & 74 \\
\hline
\end{tabular}

reports to be ready this require about 15-20 days with the need of experience of a professional pathologist. In addition to that, the need for the presence of caseating tubercle granuloma is a must for strong evidence of the diagnosis although some cases do not show this evidence [12], [13]. In certain cases of EBTB, rapid diagnosis and initiation of early anti-tuberculous therapy is mandatory to save patients life and this urges the need for rapid and sensitive methods for the early diagnosis. Molecular detection of TB bacilli arises before many years ago to satisfy this demand. However, the detection of TB bacilli in FFPE sample is a challenging technique for acquiring good results, this depends on many factors such as the fixation protocol, the age of the paraffin block, and the presence of endogenous or exogenous inhibitors of the reaction [10], [14].

Among the 74 patients selected in this study, $66 \%$ of them are presented with cervical lymph node enlargement from those with LAP, this is in consistent with what was reported previously [15]. Tuberculous lymphadenitis is one of the most common presentations of extrapulmonary TB with rapid and accurate diagnosis is very essential as delaying in the diagnosis results in high risk of complications such as suppuration and fistula formation while the confirmed early diagnosis is required to initiate systemic anti-tuberculous therapy. Furthermore, there is a challenging issue in the diagnosis since there is a possibility of nontuberculous lymphadenitis in the differential diagnosis of neck lymph node mass. In this study, $85 \%$ of cervical lymphadenitis is positive for both histopathology and PCR, while $13 \%$ are negative for PCR only with histopathology of less evidence for TB. This is can be explained by the fact that there are many diseases can give histopathological features of noncaseating granuloma such as sarcoidosis, then there is a possibility that the $13 \%$ of cases that gave negative PCR may be included in this group of disease [16], [17].

For the axillary mass, it represents $16 \%$ from samples enrolled in this study; however, there are $66 \%$ of axillary mass samples were positive for both PCR and histopathology. This can be explained by the fact that there are many diseases (both benign and malignant) may presented with axillary mass. For the malignant one, lymphoma and metastatic breast cancer, lung, and thyroid cancers may presented with axillary mass. However, benign granulomatous mass may be infectious (TB, toxoplasmosis) and noninfectious (sarcoidosis and berylliosis) [18].

For the intestinal samples, they represent $5.4 \%$ of the total samples with $50 \%$ showed positive PCR with low evidence of TB in histopathology while the other $50 \%$ showed negative PCR. One explanation for this is that inflammatory bowel disease especially Crohn's disease represents an important dilemma in differentiation from TB [19]. PCR will resolve this problem as one protocol for the differentiation is to give anti-tuberculous drugs as a therapeutic trial. 
The limitations of this study are: low samples number, the patients whose their FFPE samples give positive or negative PCR results should be followed up to prove the diagnosis, other tests such as Interferon Gamma Release Assay is needed although it is not confirmatory it may give an idea for the patient status, and the PCR tests required to be done both on fresh and FFPE samples to overcome the factors that may affect the results.

\section{Conclusion}

In conclusion, this study showed that there is an agreements between histopathology and PCR in regards to sensitivity and specificity $(91.02 \%$ and $88.2 \%$ respectively).

\section{References}

1. Tuberculosis. Available from: https://www.who.int/health-topics/ tuberculosis\#tab=tab_1. [Last accessed on $2021 \mathrm{Mar}$ 21].

2. Golden MP, Vikram HR. Extrapulmonary tuberculosis: An overview. Am Fam Physician. 2005;72(9):1761-8. PMid: 16300038

3. Ketata W, Rekik WK, Ayadi H, Kammoun S. Extrapulmonary tuberculosis. Rev Pneumol Clin. 2015;71(2-3):83-92. PMid:25131362

4. Raveendran R, Wattal C. Utility of multiplex real-time PCR in the diagnosis of extrapulmonary tuberculosis. Braz J Infect Dis. 2016;20(3):235-41. https://doi.org/10.1016/j.bjid.2016.01.006 PMid:27020707

5. Farazi A, Moharamkhani A, Sofian M. Validity of serum adenosine deaminase in diagnosis of tuberculosis. Pan Afr Med J. 2013;15:133. https://doi.org/10.11604/pamj.2013.15.133.2100 PMid:24319523

6. Jairajpuri Z, Rana S, Farooqui M, Rana S, Anees A, Ahmad Z. The role of laboratory investigations in evaluating abdominal tuberculosis. J Fam Community Med. 2015;22(3):152. https:// doi.org/10.4103/2230-8229.163029 PMid:26392795

7. Suh S, Lee O, Choi H, Kee S, Shin J, Ryang D, et al. Use in routine clinical practice of two commercial real-time PCR assays for detection of Mycobacterium tuberculosis complex: Comparison of cobas taqman MTB test and advansure TB/ NTM real-time PCR. J Mol Diagn. 2013;15(6):888. https://doi. org/10.3343/alm.2015.35.3.356

8. Salian NV, Rish JA, Eisenach KD, Cave MD, Bates JH. Polymerase chain reaction to detect Mycobacterium tuberculosis in histologic specimens. Am J Respir Crit Care Med. 1998;158(4):1150-5. https://doi.org/10.1164/ ajrccm.158.4.9802034

\section{PMid:9769274}

9. Denkinger CM, Schumacher SG, Boehme CC, Dendukuri N, Pai M, Steingart KR. Xpert MTB/RIF assay for the diagnosis of extrapulmonary tuberculosis: A systematic review and meta-analysis. Eur Respir J. 2014;44(2):435-46. https://doi. org/10.1183/09031936.00007814

PMid:24696113

10. Johansen IS, Thomsen VØ, Forsgren A, Hansen BF, Lundgren B. Detection of Mycobacterium tuberculosis complex in formalin-fixed, paraffin-embedded tissue specimens with necrotizing granulomatous inflammation by strand displacement amplification. J Mol Diagn. 2004;6(3):231-6. https://doi. org/10.1016/s1525-1578(10)60515-6

PMid: 15269300

11. Ahmed HG, Nassar AS, Ginawi I. Screening for tuberculosis and its histological pattern in patients with enlarged lymph node. Patholog Res Int. 2011;2011:417635. https://doi. org/10.4061/2011/417635

PMid:21660265

12. Pandey V, Chawla K, Acharya K, Rao S, Rao S. The role of polymerase chain reaction in the management of osteoarticular tuberculosis. Int Orthop. 2009;33(3):801-5. https://doi. org/10.1007/s00264-007-0485-8

PMid: 18038134

13. Park DY, Kim JY, Choi KU, Lee JS, Lee CH, Sol MY, et al. Comparison of polymerase chain reaction with histopathologic features for diagnosis of tuberculosis in formalin-fixed, paraffin-embedded histologic specimens. Arch Pathol Lab Med. 2003;127(3):326-30. https://doi. org/10.5858/2003-127-0326-copcrw PMid: 12653577

14. Greer CE, Lund JK, Manos MM. PCR amplification from paraffin-embedded tissues: Recommendations on fixatives for long-term storage and prospective studies. PCR Methods Appl. 1991;1(1):46-50. https://doi.org/10.1101/gr.1.1.46 PMid:1842921

15. Kathamuthu GR, Moideen K, Baskaran D, Sekar G, Rathinam S Bharathi $\mathrm{VJ}$, et al. Tuberculous lymphadenitis is associated with altered levels of circulating angiogenic factors. Int J Tuberc Lung Dis. 2018;22(5):557-66. https://doi.org/10.5588/ijtld.17.0609 PMid:29663962

16. Mortaz E, Masjedi MR, Matroodi S, Abedini A, Kiani A, Soroush $\mathrm{D}$, et al. Concomitant patterns of tuberculosis and sarcoidosis. Tanaffos. 2013;12(4):6-9. https://doi.org/10.1016/j. ijmyco.2016.09.031

PMid:25191477

17. Zhou Y, Wei YR, Zhang Y, Du SS, Baughman RP, Li HP. Real-time quantitative reverse transcription-polymerase chain reaction to detect propionibacterial ribosomal RNA in the lymph nodes of Chinese patients with sarcoidosis. Clin Exp Immunol. 2015;181(3):511-7. https://doi.org/10.1111/cei.12650 PMid:25959360

18. Asano S. Granulomatous lymphadenitis. J Clin Exp Hematop. 2012;52(1):1-16. PMid:22706525

19. Kedia S, Das P, Madhusudhan KS, Dattagupta S, Sharma R, Sahni $P$, et al. Differentiating Crohn's disease from intestinal tuberculosis. World J Gastroenterol. 2019;25(4):418-32. https:// doi.org/10.3748/wjg.v25.i4.418

PMid:30700939 